\section{A qualitative investigation into the effects of pragmatic instruction on Iranian EFL learners' production of suggestions and requests}

Ghavamnia, Maedeh $\bowtie$
University of Isfahan, Iran (ghavamniam@yahoo.com)

Eslami-Rasekh, Abbass

University of Isfahan, Iran (abbasseslamirasekh@yahoo.com)

Vahid Dastjerdi, Hossein

University of Isfahan, Iran (h_vahid@yahoo.com)

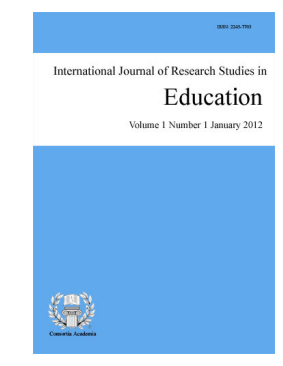

ISSN: 2243-7703 Online ISSN: 2243-7711

OPEN ACCESS

\title{
Abstract
}

Due to the fact that unlike grammatical errors, pragmatic errors may cause communication breakdown, studies in the area of interlanguage pragmatics have placed greater emphasis on the instruction of second/foreign language pragmatics. As thus, the present study investigated the relative effectiveness of four types of input-based instruction on the type of strategies the Iranian learners' of English used in making suggestions and requests. Over a 16 week course, input delivered through video clips was enhanced through: a) metapragmatic explanation $(\mathrm{N}=21)$, b) form-comparison $(\mathrm{N}=21)$, c) meaning-focused $(\mathrm{N}=28)$, and $\mathrm{d})$ typographically enhanced input at a university in Iran with female undergraduates majoring in English Translation. The four treatment groups were compared with a control group $(\mathrm{N}=15)$ on the strategies they used for making suggestions and requests on the pre-tests and post-tests, consisting of two production tasks: leaving a message on an answering machine and sending an email. The qualitative analysis of the utterances produced by the participants indicated that there was a great shift in the strategies the participants used from informal and inappropriate to appropriate strategies. The results are discussed with implications for classroom practices and future research.

Keywords: EFL context; input-based instruction; pragmatic instruction; requests; suggestions; qualitative research 


\section{A qualitative investigation into the effects of pragmatic instruction on Iranian EFL learners' production of suggestions and requests}

\section{Introduction}

The word pragmatics was a newcomer on the scene when it was introduced into linguistics in the 1980s but had been used before that to refer to one of the branches of inquiry in the philosopher Charles Morris's (1938) threefold division of semiotics (the theory of signs) into syntax, semantics, and pragmatics. Syntax described the combination of signs, semantics the relationship between signs and their meaning, while pragmatics referred to the relationship between signs and their interpreters. According to Liu (2007), Charles Morris introduced the first modern definition of pragmatics, and since then many other specialists have continued to define and broaden this branch of linguistics. More recently, Kasper (1993) defined the term as "the study of people's comprehension and production of linguistic action in context" (p. 3). In this definition context and production as two relevant elements of pragmatics are introduced that are fundamentals of any speech act in a language.

It was not until the late 1980s that the research field of pragmatics, or the study of language in use, came to be regarded as a discipline in its own right. This was based on the work of a series of philosophers of language such as Austin (1962), Searle (1969), and Grice (1975). Prior to that, researchers such as Saussure (1959) and Chomsky (1965) had only paid attention to isolated linguistic forms and structures. Both Saussure's concepts of langue and parole from the paradigm of structuralism and Chomsky's generative-transformational grammar based on the notions of competence and performance only took into consideration an ideal grammatical knowledge by native speakers of a given language. However, neither of the two paradigms took into account the real use of language in a particular context. In other words, they did not regard the notion of communication.

In relation to communicative competence in second language classrooms, sociolinguistic and pragmatic issues are important in developing pedagogy. In the past, the pedagogical emphasis was on the teaching of grammatical accuracy to the exclusion of pragmatic aspects. The result was learners' and teachers' disappointment and frustration because, in spite of the learners' relative proficiency in grammar, they still lacked the ability to express themselves appropriately. The pragmatic failure in second language learning generated much interest in the field of interlanguage pragmatics. As thus, one of the main concerns in the field of second language acquisition has become the acquisition of learners' pragmatic competence in order to be communicatively efficient in a second or a foreign language setting.

Studies have shown that the pragmatic competence of learners and native speakers vary to a great extent. Research has also revealed that even learners who are linguistically competent may be different regarding their pragmatic competence in comparison to native speakers in conversations (Bardovi-Harlig \& Hartford, 1990, 1991, 1993; Omar, 1991, 1992) and elicited conditions (e.g., Faerch \& Kasper, 1989; House \& Kasper, 1987; Takahashi \& Beebe, 1987; Takenoya, 1995). In other words, a positive relationship does not exist among language learners grammatical and pragmatic knowledge or, more specifically, "between the lexico-grammatical micro-level and the macro-level of communicative intent and sociocultural context" (Celce-Murcia, Dörnyei, \& Thurrell, 1995, p. 13).

The difference between learners' and native speakers' pragmatic competence could be related to the availability of input and the prominence of relevant linguistic features in the input. Authors such as Bardovi-Harlig and Hartford (1996) and Kasper (1997) argue that status-appropriate input is often limited or absent from the status-unequal encounters that characterize talk in advising sessions and classrooms, which leads to learners' insufficient development of pragmatic competence in the target language. Studies of the impact of instruction (House, 1996; Wildner-Bassett, 1984) and suggestions for greater authenticity in pedagogical materials for classroom language learners also take into consideration the issue of availability of input that is 
making input available to learners (Bardovi-Harlig et al., 1996; Holmes \& Brown, 1987; Scotton \& Bernsten, 1988; Williams, 1988). According to Kasper "there must be pertinent input, the input has to be noticed and learners need ample opportunity to develop a high level of control" (p. 148). Schmidt (1993) also argues that attention to "linguistic forms, functional meanings and the relevant contextual features" is necessary for pragmatic learning to occur (p. 35).

Since researchers have mainly dedicated their investigations toward examining L2 learners' pragmatic comprehension and production, the instruction of pragmatics has had a brief history and is quite new. In the past 10 years research on instructional intervention has gradually and steadily increased. The main objective of these empirical studies has been examining the effect of explicit and implicit instruction on pragmatic learning. Prior to that, between 1981 and 2001 (Kasper, 2001a, 2001b) researchers examined the teachability of different aspects of pragmatics, such as various speech acts, conversational implicature, hedges, gambits, discourse strategies and interactional markers. In relation to pragmatic instruction, most pragmatists (Billmyer, 1990; Bouton, 1994; Fukuya, 1998; Kondo, 2001; Kubota, 1995; Liddicoat \& Crozet, 2001; LoCastro, 1997; Lyster, 1994; Morrow, 1995; Olshtain \& Cohen, 1990; Rose \& Ng, 2001; Wilder-Bassett, 1994; Wishnoff, 1999; Yoshimi, 2001) have examined the effects of explicit instruction. These studies have shown that the provision of metapragmatic information works for adult learners, regardless of whether they are beginning, intermediate or advanced in either second or foreign language settings. Other researchers (House, 1996; House \& Kasper, 1981; Pearson, 1998; Takahashi, 2001; Tateyama, 2001; Tateyama et al., 1997) have compared explicit with implicit instruction. Although explicit instruction has demonstrated some advantage over implicit instruction, only Takahashi (2001) among these studies has shown statistically significant effects for the explicit instruction on pragmatic learning over implicit instruction.

Explicit instruction has been operationalized through activities which provide metapragmatic information such as: a) explanation of rules and discussion about rules (Kubota, 1995; Olshtain \& Cohen, 1990), b) metapragmatic judgment tasks (Morrow, 1995), c) introduction and analysis of prescribed speech-act formulae (Kondo, 2001; Morrow, 1995), d) narrative reconstruction (Liddicoat \& Crozet, 2001), e) rule-discovery (Rose \& $\mathrm{Ng}, 2001$ ) and f) consciousness-raising tasks (Fukuya, 1998). In contrast, implicit instruction of pragmatic features seems to be a somewhat underdeveloped area, both conceptually and methodologically. Among six studies including an implicit condition, House (1996) and House and Kasper (1981) operationalized implicit instruction by omitting the metalinguistic information, that is, the metalinguistic information the comparable explicit condition received. Alternatively, other pragmatists have conceptualized the implicit instruction as additional, simple exposure to pragmatic examples while an explicit group received the metalinguistic information in addition to such examples. Learners in the studies conducted by Pearson (1998), Tateyama (2001), and Tateyama et al. (1997) merely watched video clips; the meaning-focused group in Takahashi (2001) simply read role-play transcripts among native speakers to answer the comprehension questions.

Overall, research that has been conducted on the instruction of pragmatic information in the second or foreign language classroom has indicated positive effects of such efforts. Research on interlanguage pragmatics has revealed that providing learners with explicit metapragmatic instruction results in more effective learning outcomes than providing them with implicit target input (e.g., House, 1996; Tateyama et al., 1997; Rose \& Ng, 2001; Takahashi, 2001; Tateyama, 2001). However, most of these studies have been quantitative and have only provided quantitative analysis. The shortcoming of the previous research in the field is that rarely have they examined the utterances produced by the participants on the pre and post-tests qualitatively.

This study has tried to fill the gap to some extent by qualitatively examining the responses of the participants on the pre-tests and post-tests in order to see how pragmatic instruction has made a difference in the EFL learners' responses. Hence, this investigation, too has examined the effect of pragmatic instruction, however, with two contrasting features which make this study unique and one of a kind. At first, the authors of this study have operationalized pragmatic instruction based on four types of enhanced input conditions consisting of: a) metapragmatic explanation, b) form-comparison, c) meaning-focused, and d) input-enhancement. Second, this 
study qualitatively examined the effect of input-based instruction of suggestions and requests in order to see what changes were made in the participants' responses on the post-tests in comparison to the pre-tests. As thus, the present study aimed to answer the following research questions:

1. How does input-based instruction affect the type of strategies Iranian learners of English use in making suggestions?

2. How does input-based instruction affect the type of strategies Iranian learners of English use in making requests?

\section{Method}

\subsection{Participants}

The EFL learners who took part in this study were all female undergraduate students majoring in English Translation at a university Iran. Five different intact classes were selected for inclusion in this study. The courses the participants in the intact classes were enrolled in included: 'paragraph development' $(\mathrm{N}=21)$, 'oral translation' $(\mathrm{N}=21)$, 'reading comprehension' $(\mathrm{N}=28)$, 'oral reproduction' $(\mathrm{N}=25)$ - which received input-based instruction and 'second language research methods' $(\mathrm{N}=15)$ - which did not receive any instruction. Instruction of the pragmatic target forms in the treatment groups were enhanced through metpragmatic explanation $(\mathrm{N}=21)$, form-comparison ( $\mathrm{N}=21)$, meaning-focused $(\mathrm{N}=28)$, and input-enhancement $(\mathrm{N}=25)$ respectively. The control group $(\mathrm{N}=15)$ did not receive any type of input-based instruction on the pragmatic target forms.

Even though research in the area of ILP has indicated that being grammatically proficient does not make one pragmatically competent, the literature has not ruled out the facilitative role of linguistic competence in the acquisition of pragmatic competence. Olshtain and Cohen (1989) report that "it often happens that non-native speakers are aware of the sociolinguistic need to apologize, yet because their linguistic competence is limited, they use erroneous language forms and produce SAs that sound deviant or even create communication failure" (p. 62). After observing that lower-level learners of Spanish had difficulty identifying the illocutionary force of suggestions and particular difficulty with negative interrogative suggestions, Koike (1996: 275) concludes that it is important to have knowledge of the target language speech acts at both the grammatical / lexical level and the pragmatic level of use. Furthermore, Bardovi-Harlig and Dornyei (1998) and Hadley (1993) suggest that pragmatics is best taught and acquired when more advanced L2 learners are involved.

Hence, by taking into consideration Bardovi-Harlig and Dornyei's (1998) and Hadley's (1993) suggestion, with the help of an English proficiency test, the intermediate EFL learners were selected to take part in this study. The students in the intact classes were asked to complete Test $500 \mathrm{D}$ from the book Nelson English Language Test by W.S. Fowler and Norman Coe in order to identify their English proficiency. The book contains 40 tests organized in ten levels from elementary to advanced levels. As claimed by the test developers, all the items on the tests have been carefully pre-tested. The 400 level is equivalent in difficulty to the Cambridge First Certificate. The 500 level tests could be used to test the proficiency of the students. Each level contains four tests which are equivalent in difficulty. Each test contains 50 items and in every case the students have to choose the correct answer from four choices.

According to the authors of this book, these tests can be used for placement, diagnosis, or evaluation of students' progress. As mentioned above, each test contains 50 questions consisting of: a) 24 items testing the comprehension of the participants through a cloze test, b) 18 items testing the participants' vocabulary knowledge, c) 4 items testing the participants' knowledge of English expressions, and d) 4 items testing the participants' knowledge of homophones. According to the authors of the book, each test is out of 50 marks and those participants who obtain a score higher than 30 are classified as advanced learners of English. The participants who were selected to take part in this study were categorized as intermediate learners of English 
The effects of pragmatic instruction on Iranian EFL learners' production of suggestions and requests

because their scores on the Nelson test ranged from 25 to 29 with a mean score of 26.8. Those who scored higher than 30 were not included in the study. As such, they were expected to have more or less a given consistency in the English grammar and also vocabulary knowledge sufficient at least to understand and perform basic communicative activities.

\subsection{Data Collection}

In order to identify the development of the participants' production of pragmatically appropriate and grammatically accurate suggestions and requests, two types of production tasks in the form of Discourse Completion Tasks (DCTs) were administered as pre-tests and post-tests. Essentially, a DCT functions to create a scenario to which a participant or informant must respond. Typically, there is an initial statement outlining the context within which a dialogue occurs. Next, the first line of the dialogue is presented, and the participant is then given an opportunity to respond in the way that she believes most appropriate. Boxer (2002) notes that "DCTs may take one of two forms: open-ended questionnaires simply ask for the subject to supply the relevant speech act in response to the stimulus (the first line); closed questionnaires elicit a speech act from the subject, but then follow the blank line with a reply from the first speaker, so that the response must take into account not only the initial statement, but also the reply to follow" (p. 15). Recognizing the limitations of DCT tasks is important (Beebe \& Cummings, 1996; Kasper \& Roever, 2005).

Among the most common criticisms of the written DCT are that the written format may not accurately reflect oral (spoken) language production, and that the task is rather artificial, reflecting what a learner believes she would say, rather than demonstrating what she actually says in conversation. Also, Watts (2003) has reported that written DCTs are particularly susceptible to manipulation by informants, resulting in responses that they would never use in actual discourse. On the other hand, Chaudron (2003) suggested that DCTs may not allow learners to sufficiently express their pragmatic competence, particularly in the sense that learners are bound to some extent by the situations presented in the DCT. In order to address such concerns, the design of the written and oral DCTs utilized for the present study included a variety of academically oriented contexts and every effort was made to encourage the participants to provide realistic responses.

The pre-tests contained 8 situations and the post-tests contained 8 situations as well. The participants were asked to provide their responses either orally by leaving a message on an answering machine or through sending an e-mail. On the phone task, the participants were asked to read four situations in which they had to make a) a suggestion to a friend at university, b) a suggestion to a professor at university, c) a request to a friend at university, and d) a request to a professor at university and for each situation, they had to dial the phone number provided by the researcher and leave a message on the friend/professor's answering machine making a request or suggestion depending on the situation. The same thing had to be done on the e-mail task, with the difference that this time they had to send an e-mail to a friend or a professor, either making a suggestion or a request again based on the situations on the DCT. The post-test was exactly the same as the pre-test except for the situations. The phone number and the e-mail address were provided by the researcher which was the professor of the participants as well. In order to see whether pragmatic instruction effects the type and frequency of the strategies the participants employed in making suggestions and requests, the responses $(\mathrm{N}=1260$ responses) the participants made on the pre-tests and post-tests were examined.

\subsection{Target forms selected for instruction}

In relation to the speech act of suggesting, the instructional foci were 12 head acts (HAs) to perform suggestions and 7 downgraders to soften the force of this speech act adopted from Martinez-Flor and Fukuya's (2005) study. They selected these target forms "considering (a) universal pragmatic strategies for speech acts (Kasper \& Schmidt, 1996), (b) the politeness theory (Brown \& Levinson, 1987), (c) previous ILP studies focusing on suggestions (Hinkel, 1994, 1997; Matsumura, 2001, 2003), and (d) native speakers' oral and written production data" (p. 466). The 12 HAs were divided into two groups depending on the sociopragmatic factor of 
Ghavamnia, M., Eslami-Rasekh, A., \& Vahid Dastjerdi, H.

status (Table 1). The downgraders which were taken into consideration were just, perhaps, think, probably, personally, maybe, I'm not sure but I think.

\section{Table 1}

Taxonomy of suggestions

\begin{tabular}{ll}
\hline \multicolumn{1}{c}{ Equal status head acts } & \multicolumn{1}{c}{ Higher status head acts } \\
\hline Why don't you ... & I would probably suggest that ... \\
Have you tried ... & Personally, I would recommend that ... \\
You can just ... & Maybe you could ... \\
You might want to ... & It would be helpful if you ... \\
Perhaps you should ... & I think it might be better to ... \\
I think you need ... & I'm not sure, but I think a good idea would be... \\
\hline
\end{tabular}

Regarding the speech act of requesting, the researcher investigated previously established categories: 'request head act strategies' and 'request supportive move strategies' developed by Hudson et al. (1995, pp. 79-80) as two major components of semantic formulae for request behavior. It must be noted that in this study the only request head act strategy under investigation was the preparatory strategy. Concerning the request supportive move strategies, all of them were taken into consideration.

\section{Request head act strategies}

1. Preparatory: Reference to preparatory conditions for feasibility of the request (direct request/ can / I was wondering if / would you mind ...)

2. Strong Hint: Similar to preparatory, but not conventionalized, requires more inferencing (Will you be going home now?)

3. Want Statement: Expresses the speakers' desire that the request action be carried out (I'd like to borrow ...)

4. Hedged Performative: Illocutionary force modified by modals or verbs expressing intention (I have to ask you ...)

5. Statement of facts: Statement that leaves the hearer no choice (I have to cancel the meeting).

\section{Request supportive move strategies}

1. Grounder: Reasons, justifications (I forgot my notebook)

2. Disarmer: Remove potential objections (I know you are very busy ...?)

3. Imposition minimizer: Reduce imposition (It shouldn't take long)

4. Preparator: Announcement of request, asking about the availability of something, permission of hearer (I'd like to ask you something)

5. Getting a pre-commitment (Would you do me a favor?)

6. Apology: (I'm sorry to bother you)

7. Gratitude: (Thanks for your work last week).

\subsection{Treatment}

Five intact classes were selected for the purpose of this study. The instructor of all the five classes was the first coauthor. The students in the treatment groups received some form of input-based instruction on the 
pragmatic features under investigation while the students in the control group were only instructed on the course material. The courses the participants were enrolled in differed from one group to the other. However, all the participants in the experimental groups engaged in the same tasks and activities when it came to the treatment. The only difference among the four experimental groups was in the way the L2 pragmatic input was enhanced and delivered to them.

The pragmatic features under investigation were instructed using a total number of 12 video clips which the researcher downloaded from YouTube. 6 of the video clips were on requests and 6 others were on suggestions. The video clips included situations in which a native speaker of English either made a suggestion or a request to a friend or a professor. The criterion for the selection of the video clips was that the suggestions and requests made were part of the target forms under investigation in this study. Video is considered a very useful tool that can provide very valuable information on target language pragmatics for L2 learners (Rose, 1994; Koike, 1995; Garza, 1996). Swaffar and Vlatten (1997) indicate that authentic foreign language videos can show learners different L2 registers and cultural contexts. In addition, they provide visual cues as well as auditory material helpful for better comprehension and learning of the content presented. According to Rose (1994), videotaped discourse, whether it is natural or scripted, contains "rich recoverable contexts which can be exploited in consciousness-raising activities" (p. 58). In this study, with the help of visual dialogues, four types of input-based instruction were applied in order to raise the learners' consciousness of pragmatic elements and facilitate their learning.

The participants in this study were all enrolled in a 16 session course that lasted 16 weeks. Each session lasted 90 minutes in which the last 30 minutes was devoted to research purposes. On the first session, the participants in all five groups were asked to complete the Nelson test. On the second session, the GJT was administered. After having completed the GJT, the participants were handed the pre-tests and asked to complete the phone and e-mail tasks prior to the third session. The actual treatment for the four experimental groups was implemented starting from the $3^{\text {rd }}$ session onto the $14^{\text {th }}$ session for a total number of 12 interventional sessions. The pragmatic features related to the speech act of suggesting were instructed on the first six sessions (sessions: $3,4,5,6,7$, and 8 ) and the ones related to the speech act of requesting were instructed on the last six sessions (sessions: $9,10,11,12,13,14)$. The participants did not receive any instruction on the $15^{\text {th }}$ and $16^{\text {th }}$ sessions. On the $16^{\text {th }}$ session, they were asked to complete the GJT once more. The questions on the GJT related to the suggestions and requests were kept consistent however the researcher changed the items that were included on the test as distractors to ensure reliability. Two weeks after the end of the course, the participants were asked to complete the post-tests by reading the situations on the post-tests and making a suggestion or request based on the situations and either leaving it on the answering machine or sending it by e-mail.

The four experimental groups first watched a video clip. Then, depending on the type of input-based instruction they received, they took part in a series of activities. Below the general trend each experimental group went through is described.

In the first experimental group $(\mathrm{N}=21)$, input was enhanced through metapragmatic explanation. The learners first watched a video clip and then the students were asked to answer a set of awareness-raising questions based on the video clip they had watched. Then, the transcript of the video clip was handed to the participants and each student read over the transcript with a partner. Finally, they received explicit instruction on the target forms and metapragmatic information about the appropriate use of the target forms.

In the second group $(\mathrm{N}=21)$ input was enhanced through form-comparison. In this group the participants first received the transcript of the video clip with this difference that the places where the native speaker had made a suggestion or a request (depending on the video clip) were omitted. Then, the participants were asked to fill in the blanks with an appropriate speech act (suggestion or request). After filling in the blanks with an appropriate form of the speech act, the instructor played the video clip for the class. Then they received the complete transcript of the video clip and each participant was asked to compare her suggestion or request 
Ghavamnia, M., Eslami-Rasekh, A., \& Vahid Dastjerdi, H.

(depending on the video clip) with the one on the transcript. They were also asked to write down the differences and similarities they spotted between their own responses as non-native speakers of English and the responses of the interlocutors on the video clips as native speakers of English.

In the third group $(\mathrm{N}=28)$ input was enhanced through meaning-focused instruction. The participants in this group first watched a video clip. Then, they were given the transcript of the video clip they had watched followed by a number of comprehension questions. They were asked to read the transcript and answer the comprehension questions. No explanation or clue was given to the participants in order to direct their attention to the speech acts. They did not in any way become suspicious of the activity because they were enrolled in a reading course and the instructor had told them at the beginning of the course that alongside working on the their course book additional texts would be brought to class for extra practice.

In the fourth group ( $\mathrm{N}=25)$ the target forms were typographically enhanced through providing the subtitles of the video clips in bold. After having watched the video clip, the participants in this group received the transcript of the video clip with the target forms highlighted as well. They were asked to read over the transcript with a partner with the aim of being able to give a summary to the class. Then, the instructor would ask a number of the students to provide oral summaries for the class depending on the amount of time the class had.

The control group ( $\mathrm{N}=15)$ just watched the video clips as an extra activity with the goal of becoming more familiar with the accent of native speakers of English.

\subsection{Data Analysis}

In order to examine the data qualitatively, the messages the participants had left on the answering machine were transcribed and the e-mails they had sent were downloaded from the internet. A total number of 1260 (110 students $\times 2$ times $\times 8$ situations) responses formed the production data. Two of the researchers went through the data and coded and categorized the data.

\section{Results and Discussion}

\subsection{Suggestions}

The qualitative analysis of the participants' responses used in making suggestions on the phone and e-mail tasks on the pre-tests and post-tests revealed that pragmatic instruction had a positive impact on the type of strategy they used in making suggestions. In order to get a clearer picture of this claim, examples from the participants' responses on the pre-tests were provided below.

In regards to the situations on the pre-tests in which the participants had to make suggestions to their professor, the most evident point was that the participants used the expression 'I suggest' without paying attention to the fact that student-professor relationship is clearly one of unequal power. In this relationship, the professor has power of control (Brown \& Levinson, 1978) over the student and the justifiable right to use influence (Leichty \& Applegate, 1991) by virtue of his/her institutionalized role. In this institutionally unequal relationship, students are therefore expected to use language that properly acknowledges their own lower institutional status and their professors' higher institutional status (Biesenbach-Lucas 2007). Contrary to the aforementioned claim, the following examples show that some of the participants in this study were unaware of this fact and hence produced inappropriate suggestions in their L2. Below, samples of the students' production data on the pre-tests (phone and e-mail) are provided. 
The effects of pragmatic instruction on Iranian EFL learners' production of suggestions and requests

a) Using 'I suggest' for making a suggestion to a professor which is an inappropriate strategy to use

$>\mathrm{Hi}$, this is Aityeh. I suggest you that you should be friendly with the students and the students work together in class.

$>$ Hello. I suggest you evaluate students based on class's activity.

$>\quad$ I suggest you teach the new lesson with power point presentation.

$>$ I suggest you should evaluate student based on giving project.

I I suggest you should be friendly with the students because this causes the atmosphere to become comfortable and more students take part in class activities.

$>$ I suggest that you should be friendly, so that the atmosphere of the class is comfortable. And the students work together more and be interested more in class. Thank you.

$>$ Hello. I suggest you be friendly in class and have group work.

$>$ Hello. My name is Soheila. I suggest you could a evaluation student based on activity class.

$>\quad$ I suggest you work with laptop more in class. Because I think a lot of students have problem with writing and they agree with my idea.

$>$ Dear professor. $\underline{\text { I suggest }}$ you repeat exercise which have been done in class and recognize the response of the students for repetition. And one more point I want to add is that your creativity and your method is considerable and I thank you for being so energetic. Thank you.

$>$ Hi dear professor. First of all, I want to thank you for you kind to us. As you are going to omit the final

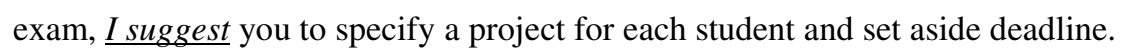

$>\quad$ Isuggest that you choose one topic and that you ask of your students that discuss about it.

b) Inappropriate strategies for making suggestions to a friend

$>$ Hi my friend. I think it's better that you take reading next semester ...

$>$ Hello. I thought about your problem and I have a good suggestion for you. I think it's better you take basic course in your courses ...

$>$ My dear. It's a good idea for improving your English proficiency that participate in conversation classes and ...

c) Inappropriate strategies for making suggestions to a professor

$>$ Hi, professor. I think if you want to omit the final exam, you should evaluate the students with their practices in the class and their homework...

$>$ Hello. You can ask the question from the student and before forgetting enter the score.

$>$ I have a suggestion for you final evaluation mark. You can introduce 20 story books ...

$>$ I recommend that it would be more valuable if you be more serious regarding students.

$>$ You should be pay attention to class activities in all session not in one or two sessions.

$>$ Hello. I have some ideas. At first, you can begin the class with a question or a starting statement. Thanks for your attention.

$>$ Hi doctor. How are you? My suggestion for you is that instead of final exam use of our grades in class and just take test of students' reading and the summarize of courses. Thanks. 
d) Making a request when a suggestion is asked for

$>$ Dear professor. My name is Nasrin. I am one of your students. I heard that you want to omit the final exam. So could it be possible for you to give our final marks based on the class activity and the projects that you will give us.

$>$ Hello professor. I was thinking about you saying you wanted to omit the final exam. I was wondering if you could replace the final exam with a project. Thank you for your time. Yours sincerely.

$>$ Dear Dr. G. Hello, I'm sending this e-mail to give a suggestion. If it's possible, would you give us a project and evaluate it as our final exam mark. Thank you.

These were just a number of examples selected from the participants' responses on the phone and e-mail pre-tests. The adoption of 'I suggest' as a strategy for making suggestions to a professor, who is higher in power than a student, could be related to L1 transfer. A useful distinction can be made between 'positive' and 'negative' transfer. When a learner uses an L2 pragmatic feature with native form, function, and distribution because of influence from the L1, this is positive transfer from the L1. However, when a learner uses an L2 pragmatic feature with non-native form, function or distribution because of L1 influence, this is negative transfer (Kasper, 1995). Hence in regards to this study, pragmatic transfer could be viewed as one potential cause of inappropriate performance. It occurs when speakers borrow rules from the L1 culture to a second or a foreign language. The phenomenon of pragmatic transfer has been investigated in different speech acts in many languages and it has been found that pragmatic transfer is evident in L2 speech performance (Jaworski, 1994; Hassall, 2003; Byon, 2004; Huth, 2006). Studies have shown that miscommunication occurs because learners of a second language need to pay close attention to its pragmatic aspects, not only to its formal aspects, such as grammar and vocabulary; however, it is the former aspect that learners frequently seem to ignore (Yu, 2011). The quantitative and qualitative findings of this study showed that pragmatic instruction could have the ability to shift the attention of the EFL learners from formal aspects to pragmatic aspects in order to produce pragmatically appropriate speech acts.

\subsection{Requests}

Concerning the speech act of requests, the qualitative analysis of the participants' responses showed that there was an improvement in the type of strategies the participants adopted. The most evident point that was spotted in the responses was that the some of the participants used 'imperative verbs' or 'can' in order to make requests to their professor on the pre-tests. Fortunately, however, the use of this strategy was rarely seen in making requests to the professor on the post-tests. Below, a number of examples have been selected from the participants' responses on the pre-tests.

a) Inappropriate strategies for making a request to a professor

Hello. I'm Zahra. I have an M.A. exam and I have the right books to study. But I don't have a lot of time. Tell me which books are important and which books have priority.

$>$ Hello doctor. How are you? I want to give exam but I don't know all the sources. Introduce me all the sources, please.

$>$ Hello professor. Please help me. I want to participate in the M.A. exam. Please introduce me some books that help me to be accept in exam.

$>$ Hello. I have problem the day that we have midterm exam. Please change the date of the exam that I can study it. I want to pass the exam. 
The effects of pragmatic instruction on Iranian EFL learners' production of suggestions and requests

I have decided to in the M.A. but I don't know which references are greater. Please help me and introduce the book that should be given priority.

$>$ Hi professor. Because of some personal problems I will not be able to attend the midterm exam. Please change the date of the exam that I will take part.

$>$ Hi doctor. I'm your student. $\underline{\text { Can }}$ you tell me which books I should read?

$>$ I don't know which ones are more important. Can you help me?

$>$ I have problem and I don't have enough time. Please change the date of exam.

$>$ Hello. Mrs. G. This is Matin. I call to ask you a request. Can you suggest me the most important references of M.A. exam ...

b) Inappropriate strategies for making a request to a friend:

$>\mathrm{Hi}, \mathrm{my}$ dear friend. $\underline{M a y} \mathrm{I}$ have a copy of your notes in order to study for midterm exam?

$>$ Hello. May I borrow your notes for short time to copy them?

$>$ Hello, $\underline{\text { may } I}$ borrow your notes for a short time?

$>$ Dear Sarah. I have a problem tomorrow and I ask you to do me a favor. Would you please manage my class tomorrow? It will be held at 5:30. If you are free that time, I really appreciate you to hold my class. Thanks a lot.

$>$ Hi, Mary. I know that this is inappropriate but $I$ was wondering if you could come to my institute tomorrow and teach my students. Something has come up and I really can't make it. Let me know if you can come tomorrow. Best wishes.

$>$ Hey, Soheila. How's it going? Listen, previous session I wasn't in a really good mood, so I couldn't take notes. Could you please bring your notes so I could get a copy of them for myself? Thank you. Bye.

$>$ Hi Moloud. How are things? Actually, I want to say something but I really don't know how to say it. Would you please give me your notes to get a copy of them? It's really kind of you. Bye.

$>$ Hi Sarah, I hope everything is going well. I am very unhappy and I need your help. I heard a bad news today and I cannot go to the institute tomorrow. So if you do not mind, could you attend class instead of me? I will make it up. Yours sincerely, Nasrin.

$>$ Dear Najmeh. How are you? Hope you and your family are doing well. Unfortunately, because of some issues I cannot make class tomorrow. Would it be possible for you to cover this class for me? Hope to hear from you soon. Best wishes, Farzaneh.

$>$ Hi Sarah. I'm Nasim. I wasn't really in the mood and I didn't write anything in Chemistry class. $\underline{\text { Could }}$ you lend me your notes to get a copy? Please call me when you arrive home.

$>$ Hi my friend. I'm Aniyeh. You know I've been attending all my classes. But I haven't been taking notes. I wonder if I could borrow your notes in order to get a copy of them for myself. Will you lend me your notes? Thank you very much for all your help. See you. Bye.

$>$ Dear Maryam. Hi. I'm writing to tell you I can't make class tomorrow. Would you mind if you attend to class instead of me? I hope you will be able to come that time. 


\section{Conclusion}

The qualitative analysis of the data indicated that the participants overused direct suggestions and requests and underused non-conventionally indirect suggestions and requests prior to pragmatic instruction. The analysis also revealed that although the intermediate participants who took part in this study were familiar with a number of realization strategies for making suggestions and requests, they used these strategies inappropriately and in an unplanned and disorderly manner. In the case of requests, for example, the participants were familiar with conventionally indirect requests such as could and may; however, in most of the cases instead of adopting these strategies for making requests to the professor they used these to make requests to a friend. The familiarity of the participants with the aforementioned strategies could be related to the fact that the grammatical structures of making requests is taught to Iranian EFL learners in the early stages of $\mathrm{L} 2$ learning. The inappropriate use of the strategies might as well be related to the fact that non-native English teachers do not allocate time to teaching how these structures are used in communication. As for the speech act of suggestions, the same pattern was observed in that the participants were familiar with a number of strategies for making suggestions however in some cases they applied the strategies in inappropriate situations. Following the interventional program, some of the suggestion and request formula had been reanalyzed and were used productively by the participants in this study. However, some non-native features remained.

Generally, the qualitative analysis of the participants' responses on the phone and e-mail tasks indicated that pragmatic instruction had a positive effect on the type of appropriate strategies the participants used in making suggestions and requests.

\subsection{Pedagogical implications}

In regards to the findings of the present investigation, the following pedagogical implications were made. In the first place, this study has shown that pragmatic instruction leads to the production of more appropriate speech acts, in this case suggestions and requests. The second implication worth emphasis is that focusing on the instruction of pragmatic features does not only take up much of the class time, but also yields constructive results. Finally, it can be claimed that various input-based instructional tasks (e.g. form-comparison, meaning-focused instruction, and input-enhancement) could be taken into consideration depending on the amount of time an English teacher has for focusing on pragmatic features which leads to pragmatically more appropriate utterances.

\section{References}

Austin, J. L. (1962). How to do things with words. Cambridge, MA: Newbury House.

Bardovi-Harlig, K., \& Dornyei, Z. (1998). Do language learners recognize pragmatic violations? Pragmatic vs. grammatical awareness in instructed L2 learning. TESOL Quarterly, 32, 233-259. http://dx.doi.org/10.2307/3587583

Bardovi-Harlig, K., \& Hartford, B. S. (1990). Congruence in native and nonnative conversations: Status balance in the academic advising session. Language Learning, 40, 467-501. http://dx.doi.org/10.1111/j.1467-1770.1990.tb00603.x

Bardovi-Harlig, K., \& Hartford, B. S. (1991). Saying "No": Native and nonnative rejections in English. In L. Bouton \& Y. Kachru (Eds.), Pragmatics and language learning (Vol. 2, pp. 41-57). Urbana-Champaign: University of Illinois, Division of English as an International Language.

Bardovi-Harlig, K., \& Hartford, B. S. (1993). Learning the rules of academic talk: A longitudinal study of pragmatic development. Studies in Second Language Acquisition, 15, 279-304. http://dx.doi.org/10.1017/S0272263100012122

Bardovi-Harlig, K., \& Hartford, B. S. (1996). Input in an institutional setting. Studies in Second Language Acquisition, 17, 171-188. http://dx.doi.org/10.1017/S027226310001487X

Bardovi-Harlig, K., Hartford, B. S., Mahan-Taylor, R., Morgan, M. J., \& Reynolds, D. W. (1996). Developing 
The effects of pragmatic instruction on Iranian EFL learners' production of suggestions and requests

pragmatic awareness: Closing the conversation. In T.Ê Hedge \& N. Whitney (Eds.), Power, pedagogy, and practice (pp. 324-337). Oxford: Oxford University Press.

Beebe, L. M., \& Cummings, M. C. (1996). Natural speech act data versus written questionnaire data: How data collection method affects speech act performance. In S. M. Gass \& J. Neu (Eds.), Speech acts across cultures (pp. 65-86). Berlin: Mouton de Gruyter.

Biesenbach-Lucas, S. (2007). Students writing emails to faculty: An examination of e-politeness among native and non-native speakers of English, Language Learning and Technology, 11(2), 59-81.

Billmyer, K. (1990). I really like your lifestyle: ESL learners learning how to compliment. PennWorking Papers in Educational Linguistics, 6(2), 31-48.

Bouton, L. F. (1994). Can NNS skill in interpreting implicature in American English be improved through explicit instruction? - A Pilot study. In L. Bouton (Ed.), Pragmatics and language learning, vol. 5 (pp. 88-109). Urbana, Ill: Division of English as an International Language Intensive English Institute, University of Illinois at Urbana-Champaign.

Brown, P., \& Levinson, S. (1978). Universals in language usage: Politeness phenomena. In Esther Goody (Ed.), Questions and politeness: Strategies in social interaction (pp. 56-289). Cambridge: Cambridge University Press.

Brown, P., \& Levinson, S. C. (1987). Politeness: Some universals in language use. Cambridge: Cambridge University Press.

Byon, A. S. (2004). Sociopragmatic analysis of Korean requests: pedagogical settings. Journal of Pragmatics, 36 , 1673-1704. http://dx.doi.org/10.1016/j.pragma.2004.05.003

Celce-Murcia, M., Dörnyei, Z., \&Thurrell, S. (1995). Communicative competence: A pedagogically motivated model with content specifications. Issues in Applied Linguistics, 6 (2), 5-35.

Chaudron, C. (2003). Data collection in SLA research. In C. J. Doughty \& M. H. Long (Eds.), The handbook of second language acquisition (pp. 762-828). http://dx.doi.org/10.1002/9780470756492.ch22

Chomsky, N. (1965). Aspect of the theory of syntax. Cambridge, MA: MIT Press.

Faerch, C., \& Kasper, G. (1989). Internal and external modification in interlanguage request realization. In S. Blum-Kulka, J. House, \& G. Kasper (Eds.), Cross-culturalpragmatics (pp. 221-247). Norwood, NJ: Ablex.

Fukuya, J. Y. (1998). Consciousness-raising of downgraders in requests. University of Hawaii at Manoa. (ERIC Document Reproduction Service No. ED466100)

Garza, T. J. (1996). The message is the medium: Using video materials to facilitate foreign language performance. Texas Papers in Foreign Language Education, 2, 1-18.

Grice, H. P. (1975). Logic and conversation. In P. Cole \& J. Morgan (Eds.). Syntax and Semantics Vol. 7 : Pragmatics (pp. 41-58). New York: Academic Press.

Hadley, A. 1993. Teaching language in context. Boston, MA, Heinle \& Heinle.

Hassall T. (2003). Requests by Australian learners of Indonesian. Journal of Pragmatics, 35(12), 1903-1928. http://dx.doi.org/10.1016/S0378-2166(03)00115-2

Hinkel, E. (1994). Native and nonnative speakers' pragmatic interpretation of English text. TESOL Quarterly, 28, 353-376. http://dx.doi.org/10.2307/3587437

Hinkel, E. (1997). Indirectness in L1 and L2 academic writing. Journal of Pragmatics, 27(3), 360-386. http://dx.doi.org/10.1016/S0378-2166(96)00040-9

Holmes, J., \& Brown, D. (1987). Teachers and students learning about compliments. TESOL Quarterly, 21, 523-546. http://dx.doi.org/10.2307/3586501

House, J. (1996). Developing pragmatic fluency in English as a foreign language: Routines and metapragmatic awareness. Studies in Second Language Acquisition, 18(2), 225-252. http://dx.doi.org/10.1017/S0272263100014893

House, J., \& Kasper, G. (1981). Zur Rolle der Kognition in Kommunikationskursen (The role of cognition in communication courses). Die Neueren Sprachen, 80, 42-55.

House, J., \& Kasper, G. (1987). Interlanguage pragmatics: Requesting in a foreign language. In W. Lorscher \& R. Schulze (Eds.), Perspectives on language performance: Festschrift for Werner Hullen (pp. 1250-1288). 
Tübingen, Germany: Gunter Narr.

Hudson, T., Detmer, E., \& Brown, J. D. (1995). Developing prototypic measures of cross-cultural pragmatics. Honolulu, HI: Second Language Teaching \& Curriculum Center, University of Hawaii.

Huth, T. (2006). Negotiating structure and culture: L2 learners' realization of L2 compliment-response sequences in talk-in-interaction. Journal of Pragmatics, 38, 2025-2050. http://dx.doi.org/10.1016/j.pragma.2006.04.010

Jaworski, A. (1994). Pragmatic failure in a second language: Greeting responses in English by Polish students. International Review of Applied Linguistics in Language Teaching, 32(1), 41-55. http://dx.doi.org/10.1515/iral.1994.32.1.41

Kasper, G. (1995). Wessen Pragmatik? Für eine Neubestimmung fremdsprachlicher Handlungskompetenz. Zeitschrift für Fremdsprachenforschung, 6, 1-25.

Kasper, G. (1997).Can Pragmatic Competence Be Taught? University of Hawaii.

Kasper, G. (2001a). Classroom research on interlanguage pragmatics. In K. R. Rose \& G. Kasper (Eds.), Pragmatics in language teaching (pp. 33-60). Cambridge: Cambridge University Press. http://dx.doi.org/10.1017/CBO9781139524797.006

Kasper, G. (2001b). Learning pragmatics in the L2 classroom. In L. Bouton (Ed.), Pragmatics and language learning (pp. 1-25). Urbana, Ill: University of Illinois at Urbana-Champaign.

Kasper, G. (Ed.) (1993). Interlanguage Pragmatics. Cary, NC: Oxford University Press.

Kasper, G., \& Roever, C. (2005). Pragmatics in second language learning. In E. Hinkel (Ed.), Handbook of research in second language learning and teaching (pp. 317-334). Mahwah, NJ: Erlbaum.

Kasper, G., \& Schmidt, R. (1996). Developmental issues in interlanguage pragmatics. Studies in Second Language Acquisition, 18, 149-169. http://dx.doi.org/10.1017/S0272263100014868

Koike, D. A. (1996). Transfer of pragmatic competence and suggestions in Spanish. In S. M. Gass \& J. Neu (Eds.), Speech acts across cultures: Challenge to communication in a second language (pp. 257-281). Berlin: De Gruyter.

Kondo, S. (2001). Instructional effects on pragmatic development: Interlanguage refusal. Paper presented at the University of Hawaii at Manoa.

Kubota, M. (1995). Teachability of conversational implicature to Japanese EFL learners. The Institute for Research in Language Teaching Bulletin, 9, 35-67.

Leichty, G., \& Applegate, J. L. (1991). Social cognitive and situational influences on the use of face-saving persuasive strategies. Human Communication Research, 17(3), 451-484. http://dx.doi.org/10.1111/j.1468-2958.1991.tb00240.x

Liddicoat, A. J., \& Crozet, C. (2001). Acquiring French interactional norms through instruction. In K. R. Rose \& G. Kasper (Eds.), Pragmatics in language teaching (pp. 125-144). Cambridge: Cambridge University Press. http://dx.doi.org/10.1017/CBO9781139524797.012

Liu, S. (2007). What is pragmatics? Retrieved from: http:// www. gxnu. edu. cn/ Personal/ szliu/ definition.html LoCastro, V. (1997). Pedagogical intervention and pragmatic competence development. Applied Language Learning, 8(1), 75-109.

Lyster, R. (1994). The effect of functional-analytic teaching on aspects of French immersion students' sociolinguistic competence. Applied Linguistics, 15(3), 263-287. http://dx.doi.org/10.1093/applin/15.3.263

Martinez-Flor, A., \& Fukuya, Y. (2005). The effects of instruction on learners' production of appropriate and accurate suggestions. System, 33, 463-480. http://dx.doi.org/10.1016/j.system.2005.06.007

Matsumura, S. (2001). Learning the rules for offering advice: A quantitative approach to second language socialization. Language Learning, 51(4), 635-679. http://dx.doi.org/10.1111/0023-8333.00170

Matsumura, S. (2003).Modelling the relationships among interlanguage pragmatic development, L2 proficiency, and exposure to L2. Applied Linguistics, 24(4), 465-491. http://dx.doi.org/10.1093/applin/24.4.465

Morris, C. (1938). Foundations of the theory of signs. In O. Neuratin., R. Carnao., \& C. Morris. (Eds.), International encyclopedia of unified science. Chicago: University of Chicago Press.

Morrow, C. K. (1995). The pragmatic effects of instruction on ESL learners' production of complaint and refusal 
The effects of pragmatic instruction on Iranian EFL learners' production of suggestions and requests

speech acts. Unpublished doctoral dissertation. Buffalo, State University of New York.

Olshtain, E., \& Blum-Kulka, S. (1985). Degree of approximation: Nonnative reactions to native speech act behavior. In S. M. Gass \& C. Madden (Eds.), Input in second language acquisition (pp. 303-325). Rowley, MA: Newbury House.

Olshtain, E., \& Cohen, A. D. (1989). Speech act behavior across languages. In H. Dechert \& M. Raupach (Eds.), Transfer in language production (pp. 53-67). Norwood, NJ: Ablex.

Olshtain, E., \& Cohen, A. D. (1990). The learning of complex speech act behavior. TESL Canada Journal, 7(2), 45-65.

Omar, A. S. (1991). How learners greet in Kiswahili. In L. Bouton \& Y. Kachru (Eds.), Pragmatics and language learning (Vol. 2, pp. 59-73). Urbana-Champaign: University of Illinois, Division of English as an International Language.

Omar, A. S. (1992). Opening and closing conversations in Kiswahili: A study of the performance of native speakers and learners. Unpublished doctoral dissertation, Indiana University, Bloomington.

Pearson, L. (1998). Spanish L2 pragmatics: The effects of metapragmatic discussion. Paper presented at Second Language Research Forum '98, University of Hawaii at Manoa.

Rose, K., \& Ng, C. (2001). Inductive and deductive teaching of compliments and compliment responses. In K. Rose \& G. Kasper (Eds.), Pragmatics in Language Teaching (pp. 145-170), Cambridge: Cambridge University Press.

Rose, R. K. (1994). Sociolinguistic consciousness-raising through video. The Language Teacher, 17, 7-9. http://dx.doi.org/10.1017/CBO9781139524797.013

Schmidt, R. (1993). Consciousness, learning and interlanguage pragmatics. In G. Kasper \& S. Blum-Kulka (Eds.) Interlanguage pragmatics (pp. 21-42). New York: Oxford University Press.

Schmidt, R. (1995). Consciousness and foreign language learning: A tutorial on the role of attention and awareness in learning. In R. Schmidt (Ed.), Attention and awareness in foreign language learning (pp. 1-63). Honolulu: University of Hawai'i, Second Language Teaching and Curriculum Center.

Scotton, C. M., \& Bernsten, J. (1988). Natural conversations as a model for textbook dialogue. Applied Linguistics, 9, 213-243. http://dx.doi.org/10.1093/applin/9.4.372

Searle, J. (1969). Speech acts: An essay in the philosophy of language. London: Cambridge University Press. http://dx.doi.org/10.1017/CBO9781139173438

Swaffar, J., \& Vlatten, A. (1997). A sequential model for video viewing in the foreign language curriculum. The Modern Language Journal, 81(2), 175-184. http://dx.doi.org/10.1111/j.1540-4781.1997.tb01173.x

Takahashi, S. (2001). The role of input enhancement in developing pragmatic competence. In: K. R. Rose \& G. Kasper (Eds.), Pragmatics in language teaching (pp. 171-199). Cambridge: Cambridge University Press. http://dx.doi.org/10.1017/CBO9781139524797.014

Takahashi, T., \& Beebe, L. (1987). The development of pragmatic competence by Japanese learners of English. JALT Journal, 8, 131-155.

Takenoya, M. (1995). Terms of address in Japanese: Patterns of use by native speakers and American learners of Japanese. Unpublished doctoral dissertation, Indiana University, Bloomington.

Tateyama, Y. (2001). Explicit and implicit teaching of pragmatics routines: Japanese sumimasen. In K. R. Rose \& G. Kasper (Eds.), Pragmatics in language teaching (pp. 200-222). Cambridge: Cambridge University Press.

Tateyama, Y., Kasper, G., Mui, L. P., Tay, H., \& Thananart, O. (1997). Explicit and implicit teaching of Japanese pragmatics routines. In L. Bouton (Ed.), Pragmatics and language learning (Vol. 8, pp. 163-177). Urbana, Ill: Division of English as an International Language Intensive English Institute, University of Illinois at Urbana-Champaign. http://dx.doi.org/10.1017/CBO9781139524797.015

Watts, R. J. (2003). Politeness. Cambridge: Cambridge University Press. http://dx.doi.org/10.1017/CBO9780511615184

Wildner-Bassett, M. (1984). Improving pragmatic aspects of learners' interlanguage. Tübingen, Germany: Gunter Narr.

Wildner-Bassett, M. A. (1994). Intercultural pragmatics and proficiency: 'Polite' noises for cultural 
Ghavamnia, M., Eslami-Rasekh, A., \& Vahid Dastjerdi, H.

appropriateness. International Review of Applied Linguistics, 32(1), 5-17.

http://dx.doi.org/10.1515/iral.1994.32.1.3

Williams, M. (1988). Language taught for meetings and language used in meetings: Is there anything in common? Applied Linguistics, 9, 45-58. http://dx.doi.org/10.1093/applin/9.1.45

Wishnoff, R. J. (1999). Hedging your bets: L2 learners' acquisition of pragmatic devices in academic writing and computer-mediated discourse. Second Language Studies, 19, 119-157.

Yoshimi, D. R. (2001). Explicit instruction and JFL learner's use of interactional discourse markers. In K. R. Rose \& G. Kasper (Eds.), Pragmatics in language teaching (pp. 223-244). Cambridge: Cambridge University Press. http://dx.doi.org/10.1017/CBO9781139524797.016 